Tarih Kültür ve Sanat Araştırmaları Dergisi

Revue des Recherches en Histoire Culture et Art

مجلة البحوث التاريخية و الثقافية والفنية
Vol. 7, No. 1, March 2018

Copyright (C) Karabuk University

http://kutaksam.karabuk.edu.tr

\title{
DOI: 10.7596/taksad.v7i1.1435
}

Citation: Miftari, V., \& Visoka, A. (2018). Myth and Memory in Medieval Literary Awareness. Journal of History Culture and Art Research, 7(1), 151-156. doi:http://dx.doi.org/10.7596/taksad.v7i1.1435

\section{Myth and Memory in Medieval Literary Awareness}

\author{
Vehbi Miftari ${ }^{1}$, Avdi Visoka $^{2}$
}

\begin{abstract}
Anne-Marie Thiesse testified that in letters, the echo of the "epic coming from the bottom of the centuries" is constantly heard. According to her, songs collected by Macpherson with the passion of the storyteller, are the substrates upon which the creation of literature transforms the great codes of different ethnicities into transcendental codes. This kind of search for the resurrection of epic ash in the letters could not carry the different ethnic and cultural feelings of the people, unless they were linked to the sign of their origin, i.e. by searching for the predecessors of a group who believes in some common values and cultivates them from generation to generation. These ancestors may be different: family members, a religious community, an ethnic community, or members of a religious community that unites the right and memories, or a cultural community, that unite some common symbols. In terms of the resurrection of "epic grace letter," they constitute a social category distinct from other categories by the language, customs, myths, religion, etc. The myths in which they believe constitute the way how they treat themselves througout history. Our paper aims to discuss this relationship between the myth and literature and the memory for common values, which at some point appear as an essence in artistic works. The scope is to analyze the report that memory has with myths and the way how both affect literature. The paper tries to study a complex relationship between letters and myths, applying it to a pattern: The Medieval Literature.
\end{abstract}

Keywords: Literature, Myth, Memory, Transcendences, Symbols, Mediaeval Literature.

\footnotetext{
${ }^{1}$ Prof. Ass. Dr., University “Haxhi Zeka”, Peja, Kosovo. E-mail: vehbi.miftari@unhz.eu

${ }^{2}$ Dr., University of Prishtina, Prishtina, Kosovo. E-mail: avdi.visoka@uni-pr.edu
} 


\section{Introduction}

Anne-Marie Thiesse testified that the echo of "epopee, coming from the bottom of the centuries" is constantly transposed in the literature. According to her, the Ossian songs, collected by James Macpherson with the passion of the storyteller, are the substrates upon which the literary work transforms the different codes into literary transcendence. This search for the resurrection of epic ash in literature would not be able to carry the feelings of the different nations, unless it was related to the sign of origin, i.e. by searching for the ancestors of a group who believes in some common values and cultivates them from generation to generation. These ancestors may be different: family members, a religious group or an ethnic community, a relative with a blood relation (creating the nucleus of ethnicity as extended kin), members of a religious community who commemorates the rite of memory, or of a cultural community, joining several common symbols. In terms of the resurrection of "epic grace in letters," they constitute a social category distinct from other categories by their identifying marks: language, customs, myths, religion, etc.

Our paper analyzes this relation between myths and literature and the memory for the set of "common values," inevitable by an artistic work. The paper also analyses the report that memory has with the rise of the "extended kinship" idea (ethnicities, nations as a large kinship). Indeed, we attribute to these kinds of kinship the function that Edmund Burke would call "a common framework created as a blood relation."

\section{Myth and Memory in Literature}

There is a permanent link between literary and epic, legendary or historical memory, expressed in a mutual relationship. This report is derived from an "organic impulse" that crystallizes the milieux de memoire (Nora, 1989) into the lieux de momoire, i.e. a tool that retrieves the common cultural and transforms it into a monument of renewal. That is why memory calls the identity as a catalyst for renewal.

It is already known that in certain historical periods, literature has been connected with the aims of the community which creates it. Thus, it becomes the bearer of her concerns, also taking an ideological function. Literature in these societies lives inseparable from their cultural, national, and ideological intentions. Ethnic or cultural community, on the other hand, being stratified over cultural traditions, accepts literature as a means of expressing and cultivating common values. Through it seeks to increase the sensitivity to commonality, with what is both inspirational and bearer of great movements. That is why modern theories consider it as a cultural product of nationalization (Anderson, 2013, p.190).

The relation between the identities and literature (debate: Herder vs Goethe) may serve as a starting point for investigating the relations that literature has with the national and cultural identities. Herder saw literature as a "remembrance of the nation," while in Osianic and Shakespeare's works, he found the principles of creating national literature. Being influenced by Osianic songs, he fought for "elevating the German nation" through his inherited culture. So, he admitted the inalienable role of literature in the identity profiling of the nations, through the renaissance of popular poetry, the living language of the nation as an "organic expression of a people."

Goethe, on the other hand, insisted that literature should not be seen as an expression of national memory and ethno-nationalist signs, but as a common domain of humanity. The examples of universal literature relativize our intention to oppose a priori this judgment. But do the heritage inheritances rely on the inherited roots? 


\section{Myth and Memory in Medieval Literature}

Let us focus for a moment in the role of myths in literature, considering A. Smith's principle of four ethnosymbolic paradigms for the creation of nations, according to which the myth ranks first, in addition to memory, tradition, and ethnic symbols (Smith, 1999, p.14).

From the aspect of theories to nations, we are constantly asking whether it would be possible for nations to be born without a mythological structure (Levi-Strauss, 2001) associated with the sign of ethnoaffiliation, or, at least, of an inherited communion. This question is equally inevitable for the so-called national literature. What categorizes them as such? What are the basic features on which national-type literature could be written and what do we mean by the "national" qualification of literature such as a language, state or territorial affiliation or motivational and thematic affiliation?

Literature is closely related to the existence of myths. It serves as a basis for literary creation, being transformed into a permanent structure, to which literature (literary text) refers whenever necessary. Because myths live forever in the literary structure, as well as in that of the nations, they get the status of being "perpetual," so they affect not only the text, but textbooks, literature. So (the ethno-) myth serves to literature as a ubiquitous structure, both at the level of discourse and forms, or ideas. At least two of the biblical myths, the Garden of Eden and Noah's Ark (Segal, 2004, p.5) stand at the heart of the myth of medieval literature. Bible myths turned into literary myths, defining the essence of the myth of literature. In his work, Henry $V$, Shakespeare, created the literal transcendence in history. The same for the legend of the Holy Grail. In addition, the legend of the grail is no longer the myth about which literature is written. It is literature itself, as a popular creation.

The above example proves that it is difficult to underline the division between myth, structure, and literature as a spiritual creation. The legend of the Holy Grail is a popular creation, which is treated as a myth over which a series of books have been written. Indeed, the myth has been linked to the legend, as a symbolism of belief in artistic creation. But likewise, it has also linked the memory of mankind and his belief in culture, religion, history, and at this what it is called zusammengehorigkeitsgefuhl (Weber, 2004).

The development of literature is unequivocally linked to the signs of the presence of myths. Medieval literature, which developed mainly as the resurgence of the ancient myth, regaining the traces of ancient epochs, constitutes the first area of the resurrection of a mythological memory.

Myths are a popular means of creating solidarity not only among members of a group but also of thinkers or writers. The myth of endurance turned into a beloved work for all the romantics. So, it has happened everywhere. This means that myth serves as solidarity with the common belief in a narrative. So far, literature becomes a means of expression for cultural transcendence.

\section{Myth and Religion in the Mediaeval Literature}

But how have the Bible's Myths been transposed into the myth of religion in the Middle Ages? Further, how did the myth of religion itself evolve from an approach to witnessing the genesis of the universe (the cosmogony) in witnessing the earthly affiliation of human life between heaven and hell, demanding an anthropological-existential identity for itself as a being which is enlightened by the presence of God?

Early medieval literature has transformed the myth of the Genesis (creation of the world) into a model for the collective life of humans over some affinity or discernment. Recapturing two Bible myths, that of the Garden of Eden and Noah's Ark (Segal, 2004, p.5), literature testifies the origin of "navel connection" with the people to which it belongs. This has led the authors to link their creativity to the mythical structure and to ask for the "respective signs" of the community they belong to. Humanists have been trying to connect literature to the universal culture of mankind. Driven by humanistic sentiments, they treated distinctiveness 
as the universal value of mankind and bringing the diversity of myths into a universal "structure" of myth. Their work, therefore, accomplishes a goal: strengthening the tradition and creating a universal model. Thus, the history becomes a myth, which is not only experienced as a story belonging to a group of people but as a myth belonging to all mankind. History, therefore, becomes a myth-to-event, i.e., a myth which revives in tangible form to man.

The two powerful myths we referred to above, Eden and Noah, are also a renewable instrument, which has a powerful function in the life of a religious community. This function is the belief in the common identities, in the precious relict of the past, from which we only preserve the "memory relict." So far, we give to these myths a social function, as they have an influence on the renewal of beliefs in the relicts of the past.

This kind of discussion about the "primitive nature of myth" explains the origin of Genesis as a starting point for searching for memory relicts in our lives. It had gained powerful functions in the Middle Ages when, in addition to Bible teachings, the myth of Genesis expanded into a philosophical discussion of his functions within our life. Myth cannot be explained in a cosmological way, but in an anthropological, even existential manner (Bultman, 1994, p.19).

This concept was decisive for bringing the cosmogonic myth much closer to the social life. The New Testament testified that human beings collide between two aspects: the heavenly (paradise) and the underworld (Hell), searching the oneself (Dantesque purgatory). Not being able to live alone (because it is dominated by heavenly or underground tendencies), he links his affiliation to the tendency to share his life with others.

The myth of the triple structure (heaven, ground and above-ground), being the core of philosophical and literary discussions in the Middle Ages, aroused a strong sense of belonging seeking, which was strongly portrayed in the literature. Because the medieval man was dominated by the aim of witnessing religious affiliation, the demand to spread his collision between the supreme and the sub grounded life (paradise and hell), he used this myth as a tool for his battle for identity. The shelter's life turned into a relic-calling to find it.

\section{Myth of Cosmogony: From Genesis to the God's Existence in Human Life}

So, the myth of cosmogony, replaced by the religious myth of religious affiliation, also made it possible to replace the topic of the myth: from Genesis to the Identity. The anthropological-existential approach to the treatment of human identity between two religions enabled man to return versus his nature, beyond the eternal nature of things. Thus, religious mythology served not anymore only as a means of cosmogony but also to understand the role of the human kind position in this world beyond the paradise-hell confrontation: Mythology enabled the knowledge and understanding of human existence (Bultman, 1984, p.19).

God's presence is no longer heavenly, it is earthly. God lives in us. His presence is expressed through the joy that man carries whenever he feels his presence within himself. So, the life of Jesus Christ, the biblical model of God's presence in human life, has become a model for searching identity (the religious or the existential). Through him, the medieval man taught the quest for belonging, treating the New Testament as a model for seeking it, and the life of Jesus Christ as the essence of God's paradoxical coexistence in dayto-day human life.

\section{Conclusions}

The echo of the past was present in the medieval literature in the form of a transcendental structure of myth. This structure was transmitted from generation to generation through a strong believe of the groups 
who believes in some common values. The members of these groups could be family members, a religious group, or members of the ethnic community. These groups accepts literature as a mean of expressing and cultivating common values. Literature is closely related to the existence of myths. The literature refers to the existence of myth, knowing her ubiquitous structure, both at the level of discourse and forms, or ideas. The Garden of Eden and Noah's Ark stand at the heart of the myth of medieval literature.

It is difficult to underline the division between myth, structure, and literature as a spiritual creation. Recapturing the above two Bible myths, that of the Garden of Eden and Noah's Ark, literature testifies the origin of "navel connection" with the people to which it belongs. This concept was decisive for bringing the myth much closer to the social life. The myth of cosmogony, replaced by the religious myth of religious affiliation, also made it possible to replace the topic of the myth: from Genesis to the Identity. This brought the God's presence much closer to the human beings. The God's presence was no longer heavenly, it became earthlier. That has determinate a model for searching identity (from religious to existential model), trying paradoxically to connect the coexistence of the life of Jesus Christ, as the essence of God's, with dayto-day human life.

\section{References}

Anderson, Benedict (1983). Imagined Communities: Reflectiones on the Origin and Spread of Nationalism. London: Verso Editions and New Left Books.

Bultman, Rudolf (1984). New Testament and Mythology and other basic Writings. Fortress Pres.

Curtius, Robert Ernst (1998). Europäische Literatur und Lateinisches Mittelalter (Frencke Verlag, Bern und München, Dritte Auflage, 1961). Cituar sipas përkthimit në gjuhën kroate: Ernst Robert Curtius, Evropska književnost i latinsko srednjovjekovlje, përkthyer nga Stjepan Markuš. Zagreb: Naprijed.

Gellner, Ernest (1987). Culture, Identity and Politics. Cambridge: Cambridge University Press.

Hobsbowm, Eric (1992). Nations and Nationalism since 1780: Programme, Myth, Reality, (2 ${ }^{\text {nd }}$ ed.). Cambridge: Cambridge University Press.

Horowitz, Donald (1982). Ethnic Groups in Conflict. Berkeley: University of California Press.

Levi-Strauss, Claude (2001). Myth and Meaning. London: Routledge.

Nora, Pierre (1989). Between Memory and History: Le Lieux de Mèmoire, translated in English by: Marc Roudebush. Representation, 26, spring.

Schwyzer, Philip (2004). Literature, Nationalism and Memory. Cambridge: Cambridge University Press.

Segal, Robert A. (2004). Myth - A very short introduction. Oxford: Oxford University Press.

Smith, Anthony D. (1999). Myths and Memories of the Nation. New York: Oxford University Press.

Smith, Anthony D. (1999). The Ethnic Origins of the Nations. New York: Blackwell Publishers LTD. 
Thiesse, Anne-Marie (2004). La création des identities nationales - Europe XVIII-XX siècle (Éditions de Seuil, Mars 1999). Cituar sipas përkthimit në gjuhën shqipe: Anne-Marie Thiesse, Krijimi i identiteteve kombëtare - Europa e shekujve XVIII-XX, përkthyer nga: Etleva Shiroka. Pejë: Dukagjini.

Weber, Max (2004). Studies in sociology. Cited the verison in Albanian: Max Weber, Studime sociologjike, translated: Enida Rusi. Tiranë: Plejad. 